\title{
Polyherbal Formulation as Potent Nutraceutical: Antioxidant and Antibacterial Activity
}

\author{
S J Kabilan, R Baskar, G Poorani
}

\begin{abstract}
The objectives of the study were to assess the potential of herbal formulation made up of Wedeliachinensis leaves and Boerhaaviadiffusa roots in possessing activities like antioxidant and antibacterial. The antioxidant potentials of the extracts were evaluated by performing DPPH radical scavenging assay and FRAP assay. The antibacterial activity was assessed using agar well diffusion method against choosed gram positive and gram negative bacterial strains. The results of the antibacterial and antioxidant activities showed that the formulation mixture of herbs Wedeliachinensis and Boerhaaviadiffusa roots is an excellent source of nutraceutical with high therapeutical importance.
\end{abstract}

Keywords: Antioxidant, Antibacterial, Boerhaaviadiffusa, Wedeliachinensis

\section{INTRODUCTION}

Wedeliachinensis (Manjalkarisalai in Tamil), Asteraceae is a well reported herbal medicine in Siddha, Unani and Ayurvedha system of traditional medicine. Recent studies show the presence of diterpenes, flavanoids, triterpenes, phytosteroids and saponins. It is also reported to possess anti-inflammatory, antioxidant, analgesic, hepatoprotective, antimicrobial, CNS depressant, wound healing, antistress and anticancer activity [6].

Boerhaaviadiffusa (Mookirattaikeerai in Tamil) is one of the well known medicinal plants that are used to treat variety of human diseased conditions as mentioned in Ayurveda, Charaka Samhita, and Sushrita Samhita [13]. Huge variety of phytochemicals like flavonoids, alkaloids, glycosides, rotenoids, steroids, lipids, triterpenoids, lignans, carbohydrates, glycoproteins and proteins etc have been reported from the herb [12]. The promising therapeutic effects of this plant include diuretic, hepatoprotective, anti-inflammatory, anti-cancer, anti-fibrinolytic, immuno-modulatory, anti-diabetic, immuno-suppressive, analgesic, anti-lymphoproliferative and used for the treatment of TB [14].

The aim of this study is to assess the polyherbal formulations ability to market as a potent Nutraceutical and also to assess the antioxidant and antibacterial efficiency.

Revised Manuscript Received on December 16, 2019

* Correspondence Author

S J Kabilan*, Department of Biotechnology, Kalasalingam Academy of Research and Education, Krishnankoil, Tamilnadu, India. Email: sjkabil@gmail.com

R Baskar, Department of Biotechnology, Kumaraguru College of Technology, Coimbatore, India. Email:baskar.r.bt@kct.ac.in

G Poorani, Department of Biotechnology, Kumaraguru College of Technology, Coimbatore, India. Email: gpoorani.biotech@gmail.com

\section{MATERIALS AND METHODS}

\section{A. Chemicals}

DPPH, methanol, ethanol, ferric chloride, TPTZ, sodium carbonate, Nutrient broth, Nutrient Agar.

\section{B. Sample collection and extraction}

Wedeliachinensis leaves and Boerhaaviadiffusa root powder were collected from an FSSAI approved herbal powder manufacturer from Coimbatore, Tamil Nadu. All herbs were stored in sealed container for future use. The samples were labeled as the Wedeliachinensis leaves (WC), Boerhaaviadiffusa (BD) and Formulation mix (F MIX).

Sample extraction

About 20g of powdered F MIX of the polyherbal formulation was successively extracted using Soxhlet extraction method with $150 \mathrm{ml}$ of distilled water. Then it is allowed to evaporate in open air to obtain aqueous extracts.

\section{In Vitro Antioxidant Activity}

DPPH Radical Scavenging assay (Alam et al. 2013)

The DPPH radical scavenging assay is based on the reduction of DPPH by the scavenging activity of antioxidants present in the extracts by the donation of protons. This was indicated by the change of color from purple to yellow which was measured by decrease in absorbance at $517 \mathrm{~nm} .0 .5 \mathrm{ml}$ of DPPH reagent was added to $2 \mathrm{ml}$ of test samples prepared in different concentrations $(100 \mu \mathrm{g} / \mathrm{ml}-600 \mu \mathrm{g} / \mathrm{ml})$ using methanol. Methanol with DPPH used as control and methanol alone as blank. The percentage inhibition or reduction of DPPH with reference to control is analyzed as the final result. The IC50 value was also determined.

Formula for finding out the percentage inhibition:

[(OD of control - OD of test $) /$ OD of control] $* 100$

where OD indicates the optical density or absorbance. A graph was plotted for the inhibition percentage vs concentration from which the value of IC50 is obtained.

Ferric Reducing Antioxidant Power (FRAP) assay (Benzie and Strain 1996)

In this assay the reduction of ferric tripyridyltriazine to ferrous tripyridyltriazine is indicated by the appearance of intense blue color which be monitored at $593 \mathrm{~nm}$. $90 \mu \mathrm{l}$ of test sample $(20 \mu \mathrm{g} / \mathrm{ml}-300 \mu \mathrm{g} / \mathrm{ml})$ was added to $2.7 \mathrm{ml}$ of the FRAP reagent and $270 \mu \mathrm{l}$ of water was added finally after which the reaction mixture was incubated at $37 \mathrm{oc}$ for 30 minutes. The increase in absorbance of the mixture was noted at $593 \mathrm{~nm}$. 


\section{Determination of Antibacterial activity}

The antibacterial activity of the aqueous extract of formulation mix was assessed by agar well diffusion method against two Gram positive bacteria and three Gram negative bacterial test pathogens. Extracts were reconstituted to a final concentration of $10 \mathrm{mg} / \mathrm{ml}$. DMSO was used as control in one of the wells. Each bacterial strain was inoculated in the Nutrient agar and from this $100 \mu \mathrm{l}$ is taken and spread on each plate. Then $100 \mu 1$ of the extracts were taken and added into the wells which were created by making punches of $6 \mathrm{~mm}$ diameter. These plates were then kept for incubation for 24 hrs at $37^{\circ} \mathrm{C}$. The diameter of the zone of inhibition was measured in millimeters to assess the antibacterial activity of the formulation extract.

\section{RESULTS AND DISCUSSION}

\section{A. In vitro Antioxidant activity}

DPPH Radical Scavenging assay (Alam et al. 2013)

The change in color from violet to pale yellow indicates that free radicals have been scavenged by the extracts. This property allows visual monitoring at $517 \mathrm{~nm}$. The scavenging activity in terms of \% inhibition of F MIX extract is given in Table I. The production of oxidative stress by free radicals causes cellular damage. Oxidative stresses have been related to cancer, inflammation, ischemic injury and neurodegenerative diseases.

Table I: Scavenging effect (in percentage) on DPPH radical by F MIX formulation

\begin{tabular}{|c|c|c|c|c|c|c|}
\hline $\begin{array}{l}\text { Sample } \\
\text { concentrat } \\
\text { ion } \\
(\mu \mathrm{g} / \mathrm{ml})\end{array}$ & 100 & 200 & 300 & 400 & 500 & 600 \\
\hline $\begin{array}{l}\% \\
\text { Inhibition }\end{array}$ & $\begin{array}{l}21.14 \\
\pm 1.69 \\
\end{array}$ & $\begin{array}{l}44.5 \\
1 \\
\pm \\
1.97 \\
\end{array}$ & $\begin{array}{l}57.2 \\
4 \\
\pm \\
0.96 \\
\end{array}$ & $\begin{array}{l}68.6 \\
3 \\
\pm \\
0.86 \\
\end{array}$ & $\begin{array}{l}71.5 \\
7 \\
\pm \\
0.84 \\
\end{array}$ & $\begin{array}{l}74.5 \\
9 \pm \\
0.56\end{array}$ \\
\hline
\end{tabular}

Fig. 1: Scavenging effect (in percentage) on DPPH radical by F MIX formulation at different concentration levels

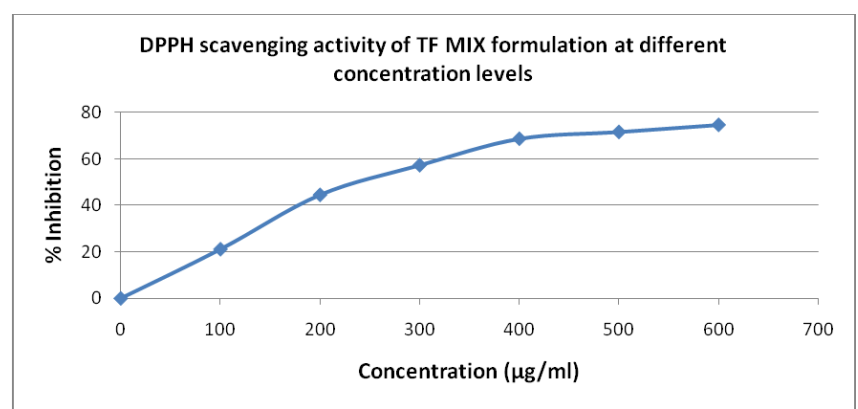

The IC50 value was found to be $243.72 \mu \mathrm{g} / \mathrm{ml}$.

This value proves that our F MIX formulation possesses better scavenging effect at lower concentrations. The antioxidant activity plays key role in the protection against toxicity -induced hepatopathy and nephropathy (Hassan et al., 2010)

FRAP assay
The presence of antioxidants in the sample was indicated by the formation of intense blue color complex with increase in absorbance at 593nm. The antioxidant activity of different concentration of F MIX extract is given in Table II.

Table II: FRAP by F MIX formulation

\begin{tabular}{|c|c|}
\hline $\begin{array}{c}\text { Sample Concentration } \\
(\mu g / \text { ml })\end{array}$ & Absorbance @ 595nm \\
\hline 20 & $0.266 \pm 0.005$ \\
\hline 40 & $0.388 \pm 0.006$ \\
\hline 60 & $0.456 \pm 0.006$ \\
\hline 80 & $0.499 \pm 0.008$ \\
\hline 100 & $0.524 \pm 0.006$ \\
\hline 200 & $0.73 \pm 0.009$ \\
\hline 300 & $0.767 \pm 0.003$ \\
\hline
\end{tabular}

Fig. 2: FRAP by F MIX formulation at different concentration levels

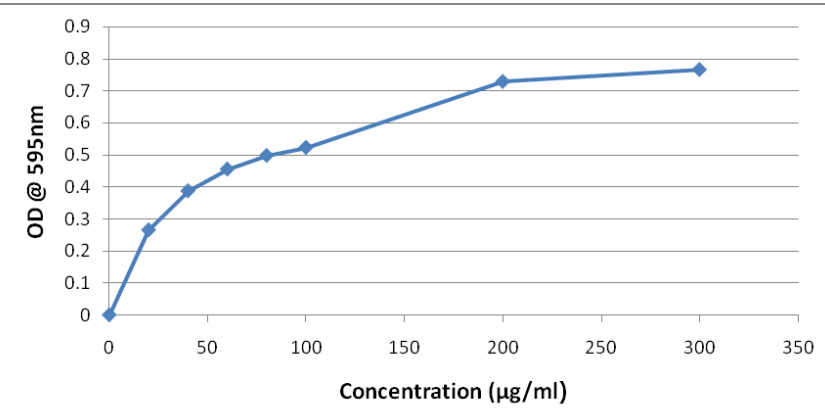

The various radical scavenging assays revealed that extract can effectively prevent the biomolecules such as DNA, polyunsaturated fatty acids, amino acids, proteins from the damage caused by the attack of reactive radical species (Kanniparambil et al., 2017).

\section{B. Determination of antibacterial activity}

Two gram positive (Enterococcus faecalis, Staphylococcus aureus) and three gram negative (E. coli, Klebsiella pneumonia, Pseudomonas aeruginosa) bacterial strains were used to evaluate the antibacterial activity of the polyherbal extract. Inhibitary concentrations used for the extract were $5 \mathrm{mg} / \mathrm{ml}$ and of crude extract. Antibacterial activity was analyzed against the standard streptomycin antibiotic disc. The zone of inhibition of the F MIX extract against various bacterial species is tabulated in the Table III.

Table III: Antibacterial activity of polyherbal formulation extracts against various bacterial strains using the agar well diffusion method

\begin{tabular}{|c|c|c|c|c|c|}
\hline \multirow[b]{2}{*}{ 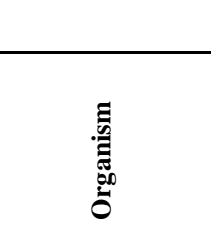 } & \multicolumn{5}{|c|}{ Diameter - Zone of Inhibition (in mm) } \\
\hline & 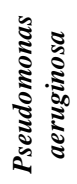 & 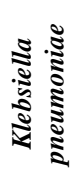 & 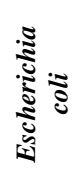 & 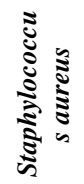 & 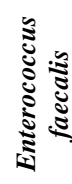 \\
\hline Crude extract & 18 & 16 & - & 14 & 11 \\
\hline $\begin{array}{c}\text { Diluted }(5 \mathrm{mg} / \mathrm{ml}) \\
\text { extract }\end{array}$ & 20 & 18 & - & 16 & 13 \\
\hline Std. Strepromycin & 25 & 20 & 23 & 19 & 16 \\
\hline
\end{tabular}


From the above table, it is evident that the F MIX formulation shows significant antibacterial activity against Pseudomonas aeruginosa, Klebsiella pneumonia, Staphylococcus aureus and Enterococcus faecalis. But, it did not show any appreciable effect over E.coli. These observations show that the formulation can prevent the infections against these organisms effectively. Prevention from bacterial infection itself will help the organ failure up to certain extent (Mistilis et al., 1970).

\section{CONCLUSION}

The results of the antibacterial and antioxidant activities showed that the formulation mixture of herbs Wedeliachinensis and Boerhaaviadiffusa roots is an excellent source of Nutraceutical with high biomedical importance. Antioxidant property proves that it can also act as anticancer agent and in anti-aging ailments. The antibacterial activity of the mixture shows that it can be used as preventive medicine against many bacterial infections.

\section{ACKNOWLEDGMENT}

The authors acknowledge Department of Biotechnology and Re forum (Research Cell) of KCT for providing essential facilities and funding to perform the research.

\section{REFERENCES}

[1] Ahmed, Mahgoub M. (2010). "Biochemical studies on nephroprotective effect of carob (Ceratonia siliqua L.) growing in Egypt." Nature and Science, Vol. 8, 3: 41-47.

[2] Alam, M. N., Bristi, N. J., \& Rafiquzzaman, M. (2013). Review on in vivo and in vitro methods evaluation of antioxidant activity. Saudi Pharmacentical Journal, 21(2), 143-152.

[3] Benzie, I. F., \& Strain, J. J. (1996). The ferric reducing ability of plasma (FRAP) as a measure of "antioxidant power": the FRAP assay. Analytical biochemistry, 239(1), 70-76.

[4] Das, M. P., Rebecca, L. J., \& Sharmila, S. (2013). Evaluation of antibacterial and antifungal efficacy of Wedelia chinensis lea extracts. Journal of Chemical and Pharmaceutical Research, 5(2), 265-9.

[5] Hassan, S. W., Salawu, K., Ladan, M. J., Hassan, L. G., Umar, R. A., \& Fatihu, M. Y. (2010). Hepatoprotective, antioxidant and phytochemical properties of leaf extracts of Newbouldia laevies. International Journal of Pharm Tech Research, 2(1), 573-584.

[6] Koul, S., Pandurangan, A., \& Khosa, R. L. (2012). Wedelia chinenis (Asteraceae)-an overview. Asian Pacific Journal of Tropical Biomedicine, 2(2), S1169-S1175.

[7] Krishnaiah, D., Devi, T., Bono, A., \& Sarbatly, R. (2009). Studies on phytochemical constituents of six Malaysian medicinal plants. Journal of medicinal plants research, 3(2), 067-072.

[8] Kumari, A., \& Bhatnagar, S. (2016). Phytochemical Analysis and Biological Evaluation of Leaf Extracts of Wedelia Chinensis. Pharm Pharmacol Int $J, 4(7), 00102$.

[9] Liao F, Folsom AR, Brancati FL. Is Low Magnesium Concentration a Risk Factor for Coronary Heart Disease? The Atherosclerosis Risk in Communities (ARIC) Study. American Heart Journal. 1998; 136(3):480-490.

[10] Mahesh, A. R., Kumar, H., Ranganath, M. K., \& Devkar, R. A. (2012). Detail study on Boerhavia Diffusa plant for its medicinal importance-a review. Res J Pharm Sci, 1, 28-36.

[11] Manjamalai, A., Jiflin, G. J. \& Grace, V. M. (2012). Study on the effect of essential oil of Wedelia chinensis (Osbeck) against microbes and inflammation. Asian J Pharm Clin Res, 5, 155-63.

[12] Mosmann, T. (1983). Rapid colorimetric assay for cellular growth and survival: application to proliferation and cytotoxicity assays. Journal of immunological methods, 65(1-2), 55-63.

[13] Murti, K., Panchal, M. A., \& Lambole, V. (2010). Pharmacological properties of Boerhaavia diffusa-a review. Int J Pharm Sci Rev Res, 5(2), 107-110
[14] Nayak, P., \& Thirunavoukkarasu, M. (2016). A review of the plant Boerhaavia diffusa: its chemistry, pharmacology and therapeutical potential.

[15] Nomani, I., Mazumder, A., \& Chakraborthy, G. S. (2013). Wedelia chinensis (Asteraceae)-An Overview Of A Potent Medicinal Herb. Int J PharmTech Res, 5(3), 957-964.

[16] Reshma, A. K., \& Brindha, P. (2014). In Vitro Anti-Inflammatory, Antioxidant and Nephroprotective Studies on Leaves of Aegle Marmelos and Ocimum Sanctum. Asian journal of pharmaceutical and clinical research, 7, 121-124.

[17] Sasidharan, S., Aravindran, S., Latha, L. Y., Vijenthi, R., Saravanan, D., \& Amutha, S. (2010). In vitro antioxidant activity and hepatoprotective effects of Lentinula edodes against paracetamol-induced hepatotoxicity. Molecules, 15(6), 4478-4489.

[18] Sharma, P., Bhardwaj, R., Yadav, A., \& Sharma, R. A. (2014) Antioxidant Properties of Methanolic Extracts of Boerhavia diffusa. Research Journal of Phytochemistry, 8(3), 119-126.

[19] Shirazi, O. U., Khattak, M. A. K., Shukri, N. A. M., \& Nasyriq, M. N. (2014). Determination of total phenolic, flavonoid content and free radical scavenging activities of common herbs and spices. Journal of Pharmacognosy and Phytochemistry, 3(3), 104-108.

[20] Toda, S. (2011). Polyphenol content and antioxidant effects in herb teas. Chinese Medicine, 2(01), 29

\section{AUTHORS PROFILE}

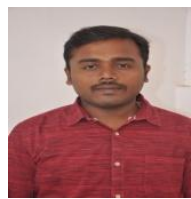

S J Kabilan, completed his B.Tech (Biotechnology) at Kalasalingam University and M.Tech (Biotechnology) at Kumaraguru College of Technology (Affiliated to Anna University). Both the Degrees completed with First class with Distinction. Also, pursuing $\mathrm{PhD}$ in the area of Herbal Drug Research.

Currently Employment: Assistant Professor, Department of Biotechnology, School of Bio and Chemical Engineering, Kalasalingam Academy of Research and Education, Tamilnadu, India.

Previous Publications: Kabilan, M. S. (2018). Antioxidant and anti-inflammatory properties of G-immune plus: A polyherbal formulation. International Journal of Green Pharmacy (IJGP), 12(03).

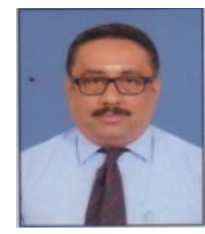

Dr. R. Baskar, $\mathrm{PhD}$ in Medical Biochemistry. Currently working as Associate professor at Kumaraguru college of Technology, Coimbatore, Tamilnadu, India.

Memberships:

Life Member in Indian Society for Technical Education Life Member in National Society for Ethnopharmacology.

\section{Achievements:}

1. INSA Summer Fellowship award during 2012 to work in the Laboratory of Plant-Microbe Interaction, School of Botany, University of Hyderabad on "Plant Growth Promoting Rhizobacteria".

2. Reviewer in National and International Journals

3. Currently Academic Editor in Biotechnology Journal International.

4. No. of citations : 792; $\mathrm{h}$ index : 12 ; i10 index : 16

Recent Publications:

- Baskar,R., Akshaya, S.B., Akshitha, R., Dhilip Kumar, G., Poorani, G. (2018).Evaluation of antioxidant and phytochemical activity in solvent extracts of Delonix regia.International Journal of Green Pharmacy, Volume 12(3), July-September issue, S607-S616.

- Baskar, R., Sweatha, S., Karunambika, R., G.Ramya, R.Shanthi (2017).

Influence of methionine on ergothineine content and antioxidant activity of Pleurotus platypus.Asian Journal of Microbiology, Biochemistry and Environmental Sciences, Volume 19 (Supplementary issue), S34-S38.

- Gurumallesh, P., Alagu, K., Ramakrishnan, B. and Muthusamy, S (2019).A systematic reconsideration on proteases.International Journal of Biological Macromolecules, 128, 254-267 (Impact Factor: 4.7)

- PooraniGurumallesh, Baskar Ramakrishnan and BhaarathiDhura (2019). A novel metalloprotease from banana peel and its biochemical characterization. International Journal of Biological Macromolecules, 134, 527- 535 (Impact factored4-7)

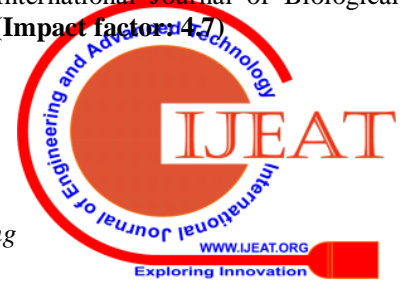


Poorani G completed her B.Tech (Biotechnology) at Tamil Nadu Agricultural University, Coimbatore and M.Tech Pharmaceutical Technology at SASTRA University, Thanjavur and currently pursuing Ph.D Kumaraguru College of Technology.

Notable Publications:

INTERNATIONAL

JOURNAL

OF

BIOLOGICAL

MACROMOLECULES (2019) IF 4.78 A novel metalloprotease from banana peel and its biochemical characterization

MATERIAL SCIENCE AND ENGINEERING C (2019) IF 5.08 Biological synergy of greener gold nanoparticles by using Coleus aromaticus leaf extract

INTERNATIONAL JOURNAL OF BIOLOGICAL MACROMOLECULES (2019) IF 4.78 A systematic reconsideration on proteases

PROCESS BIOCHEMISTRY (2019) IF 2.88 Green synthesis of anisotropic silver nanoparticles from the aqueous leaf extract of Dodonaeaviscosa with their Antibacterial and Anticancer activities

JOURNAL OF PHOTOCHEMISTRY AND PHOTOBIOLOGY B: BIOLOGY (2018) IF 4.06 Improved Conductivity and Antibacterial activity of poly (2- aminothiophenol) - silver nanocomposite against human pathogens

JOURNAL OF MICROENCAPSULATION (2016) IF 2.04 Formulation, characterization, in vitro and in vivo evaluation of castor oil based self-nano emulsifying levosulpiride delivery systems 